\begin{tabular}{|c|c|c|}
\hline institute & $\begin{array}{l}\text { CARADDE: Jurnal Pengabdian Kepada Masyarakat } \\
\text { https://journal.ilininstitute.com/index.php/caradde } \\
\text { Volume } 2 \text { | Nomor 1 | Agustus |2019 } \\
\text { e-ISSN: } 2621-7910 \text { dan p-ISSN: 2621-7961 } \\
\text { DOI: https://doi.org/10.31960/caradde.v2i1.95 }\end{array}$ & \begin{tabular}{|l|} 
GaiN \\
CaRADOE \\
\end{tabular} \\
\hline
\end{tabular}

\title{
Sosialisasi Perhitungan Dan Pelaporan Wajib Pajak Usaha Mikro, Kecil Dan Menengah (UMKM) Kota Semarang
}

\author{
Saryadi $^{1}$, Robetmi Jumpakita Pinem ${ }^{2}$
}

\begin{tabular}{ll}
\hline \hline Keywords: & Abstrak. Pengabdian masyarakat ini berttujuan untuk \\
Sosialisasi; & membantu masyarakat untuk memahami pengampunan pajak, \\
tax amnesty; & penghitungan dan pelaporan pajak sehingga membantu Dirjen \\
UMKM & Pajak dalam mensosialisasikan pajak pelaku UMKM. Program \\
& pengabdian yang menjadi prioritas untuk dilaksanakan adalah \\
Corespondensi Author & sosialisasi perhitungan dan pelaporan wajib pajak usaha mikro, \\
Robetmi Jumpakita Pinem & kecil dan menengah (UMKM) Kota Semarang. Metode \\
Email: & pelaksanaan pengabdian ini menggunakan metode participatory \\
robetmijumpakita@yahoo.com & rural appraisal (PRA) adalah teknik yang memungkinkan \\
Departemen Administrasi Bisnis & masyarakat untuk turut serta dalam membuat tindakan nyata \\
Fakultas Ilmu Sosial dan Ilmu & rencana, pengawasan, dan evaluasi kebijakan yang berpengaruh \\
Politik Universitas Diponegoro & pada kehidupannya. Alasan mereka tidak mengikuti tax amnesty \\
Jl. Prof.Sudharto, Tembalang, & adalah sebagian pengusaha menyatakan tidak adanya sosialisasi \\
Semarang, Jawa Tengah & dari pemerintah, dan sebagian menyatakan sudah melakukan \\
& pembayaran pajak usaha secara rutin, sehingga tidak perlu \\
History Artikel & mengikuti program pengampunan pajak / tax amnesty. \\
Received: Januari-2019; & Pengabdian kepada masyarakat ini yaitu Kota Semarang \\
Reviewed: April-2019 & mempunyai potensi wajib pajak UMKM yang bisa menambah \\
Accepted: April-2019 & pemasukan negara, memalui semakin gencarnya disosialisasikan \\
Published: Juni-2019 & kesadaran akan pajak maka pelaku wajib pajak akan ikut \\
& melaporkan pajaknya. Sosialisasi penghitungan dan pelaporan \\
& pajak mampu mempermudah pelaku UMKM dalam melaporkan \\
& pajaknya karena selama ini tidak melaporkan karena \\
& ketidaktahuan dan cara pelaporannya.
\end{tabular}

(1) This work is licensed under a Creative Commons Attribution

4.0 International License

\section{PENDAHULUAN}

Pembangunan nasional yang berlangsung secara terus-menerus dan berkesinambungan selama ini, bertujuan meningkatkan kesejahteraan rakyat baik materiil dan spiritual. Untuk merealisasikan tujuan tersebut diperlukan anggaran pembangunan yang cukup besar. Salah satu usaha untuk mewujudkan peningkatan penerimaan untuk pembangunan tersebut adalah dengan menggali sumber dana yang berasal dari dalam negeri, yaitu pajak. Secara ekonomi, pemungutan pajak merupakan penerimaan negara yang digunakan untuk meningkatkan taraf kehidupan masyarakat. (Agung, Mulyo 2007). Taraf hidup masyarakat akan meningkat diperlukan anggaran yang selalu meningkat pula.

Pada tanggal 1 Juli 2016 Pemerintah Republik Indonesia mengeluarakan UndangUndang Nomor 11 Tahun 2016 tentang "Pengampunan Pajak". Pengampunan Pajak merupakan penghapusan pajak yang seharusnya terutang, tidak dikenai sanksi 
administrasi perpajakan dan sanksi pidana di bidang perpajakan. Kewajiban perpajakan yang mendapatkan pengampunan Pajak terdiri atas kewajiban Pajak Penghasilan (PPh), Pajak Pertambahan Nilai (PPN), dan Pajak Penjualan atas Barang Mewah (PPnBM).

Penerimaan negara dari sektor pajak secara keseluruhan per 31 Desember 2016 mencapai Rp1.105 trilliun atau sebesar 81,54 persen dari target penerimaan pajak APBN Perubahan 2016 sebesar Rp1.533 trilliun. Jumlah penerimaan negara itu sudah meliputi amnesti pajak periode pertama dan kedua hingga 31 Desember 2016. Untuk dana repatriasi luar negeri yang masuk sebesar Rp141 triliun.

Indrawan, dkk (2018) menunjukkan bahwa pengetahuan dan pemahaman tentang pajak menunjukkan kepatuhan terhadap pajak bagi pelaku UMKM. Mekanisme pembayaran pajak yang semakin dipermudah juga akan meningkatkan kepatuhan terhadap pembayaran pajak (Ayu, 2017, Yusro, dkk., 2014). Kesederhanaan dalam sistem pemungutan pajak akan membantu ketaatan pembayaran pajak (Endrianto, 2015, Munari, 2005).

Pelayanan petugas pajak meningkatkan kepatuhan bayar pajak (Supadmi, 2010, Winerungan, dkk., 2013). Primandani, dkk. (2017) menyatakan bahwa kemudahan dan pelayanan akan meningkatkan kepedulian wajib pajak untuk membayar kewajiban pajak.

Tujuan dikeluarkannya UndangUndang Pengampunan Pajak adalah untuk: Mempercepat pertumbuhan dan restrukturisasi ekonomi melalui pengalihan Harta, yang antara lain akan berdampak terhadap peningkatan likuiditas domestik, perbaikan nilai tukar Rupiah, penurunan suku bunga, dan peningkatan investasi;

Mendorong reformasi perpajakan menuju sistem perpajakan yang lebih berkeadilan serta perluasan basis data perpajakan yang lebih valid, komprehensif, dan terintegrasi; dan

Meningkatkan penerimaan pajak, yang antara lain akan digunakan untuk pembiayaan pembangunan. (UU No. $11 \mathrm{Th}$. 2016).

Menurut UU No. 11 Tahun 2016 tentang Pengampunan Pajak, Penentuan kriteria Wajib Pajak UMKM didasarkan pada jumlah peredaran usaha dalam satu tahun yang dimiliki oleh Wajib Pajak. Jumlah Peredaran usaha yang termasuk ke dalam kriteria Wajib Pajak UMKM sesuai UndangUndang Nomor 11 Tahun 2016 adalah Wajib Pajak yang memiliki peredaran usaha sampai dengan $\mathrm{Rp}$ 4,8 Milyar dalam satu tahun. Dalam Pasal 11 UU Pengampunan Pajak dijelaskan bahwa Wajib Pajak UMKM merupakan Wajib Pajak yang memiliki peredaran usaha hanya bersumber atas kegiatan usaha termasuk disini kegiatan usaha yang bersifat non final (Pasal 4 ayat 1) dan bersifat final (Pasal 4 ayat 2); dan tidak menerima penghasilan dari pekerjaan dalam hubungan kerja dan/atau pekerjaan bebas (Pekerjaan bebas merupakan pekerjaan yang dilakukan oleh orang pribadi yang mempunyai keahlian khsus sebagai usaha untuk memperoleh penghailan yang tidak terikat oleh suatu hubungan kerja, antara lain dokter, notaris, akuntan, arsitek, atau pengacara).

Tarif UMKM dalam pengampunan pajak dalam pasal 4 ayat (3) UU pengampunan pajak disebutkan bahwa tarif uang tebusan bagi Wajib Pajak yang peredaran usahanya sampai dengan Rp. 4.800.000.000 pada tahun pajak terakhir, dasar pengenaan uang tebusan adalah sebesar : $0,5 \%$ bagi Wajib Pajak yang mengungkapkan nilai Harta sampai dengan Rp. 10 Miliar dalam Surat Pernyataan. Dan $2 \%$ bagi Wajib Pajak yang mengungkapkan nilai Harta lebih dari Rp. 10 Miliar dalam Surat Pernyataan.

Kariyoto, dkk. (2012) menyebutkan bahwa kesadaran wajib pajak berpengaruh terhadap kepatuhan wajib pajak. Kesadaran wajib pajak UMKM masih rendah di kota Semarang, berdasarkan hasil penelitian yang telah dilakukan pada UMKM yang menjalankan usaha batik di Kota Semarang yang menjadi pusat belanja batik di Semarang terhadap kebijakan pemerintah atas program tax amnesty yang sudah disosialisasikan pemerintah sejak 2016.

Berdasarkan data pelaku usaha UMKM kampung batik Kota Semarang dominan perusahaan perseorangan atau sebanyak 5 usaha atau $71,4 \%$ dan 1 usaha 
sudah berbentuk CV dan 1 usaha belum berbadan hukum, Peraturan Menteri Keuangan (PMK) Nomor 197/PMK.03/2013 bahwa tidak mewajibkan melaporkan pajak usaha. Artinya kebanyakan usaha yang ada di kampung batik Kota Semarang kebanyakan belum berbadan hukum. 4 dari 7 pelaku usaha sudah memiliki NPWP atau sebesar $57,1 \%$ dan yang belum memiliki NPWP sebanyak 3 usaha artinya bahwa sudah lebih dari setengah yang memiliki NPWP dan taat pajak.

Pelaku UMKM Tambakharjo Kota Semarang memiliki beberapa pelaku UMKM yang berdasarkan survey awal masih banyak yang belum paham penghitungan dan pelaporan pajak termasuk kebijakan pengampunan pajak sehingga kita melakukan sosialisasi perhitungan dan pelaporan wajib pajak usaha mikro, kecil dan menengah (UMKM) di Kelurahan Tambakharjo, Kecamatan Semarang Barat kota Semarang untuk membantu Pemerintah meningkatkan pendapatan negara melalui sektor Pajak dan membantu mempermudah pelaku UMKM yang ingin membayar tapi tidak tahu cara untuk melaporkan SPT usaha.

\section{METODE}

Metode pelaksanaan pengabdian ini menggunakan metode participatory rural appraisal (PRA) adalah teknik yang memungkinkan masyarakat untuk turut serta dalam membuat tindakan nyata rencana, pengawasan, dan evaluasi kebijakan yang berpengaruh pada kehidupannya. PRA bukan hanya terdiri dari riset, melainkan juga perencanaan (partisipatif), monitoring, dan evaluasi.

Berikut adalah prinsip-prinsip gabungan menurut Adimihardja \& Hikmat (2003) serta Bhandari (2003): (1) Masyarakat dipandang sebagai subjek bukan objek; (2) Orang luar sebagai fasilitator dan masyarakat sebagai pelaku; (3) Peneliti memposisikan dirinya sebagai insider bukan outsider; (4) Fokus pada topik utama permasalahan; (5) Pemberdayaan dan partisipatif masyarakat dalam menentukan indikator sosial (indikator evaluasi partisipatif). Kemampuan masyarakat ditingkatkan melalui proses pengkajian keadaan, pengambilan keputusan, penentuan kebijakan, peilaian, dan koreksi terhadap kegiatan yang dilakukan; (6) Keterlibatan semua anggota kelompok dan menghargai perbedaan; (7) Konsep triangulasi. Untuk bisa mendapatkan informasi yang kedalamannya dapat diandalkan, bisa digunakan konsep triangulasi yang merupakan bentuk pemeriksaan dan pemeriksaan ulang (check and recheck); (8) Optimalisasi hasil.

Dengan dilibatkannya masyarakat dalam proses program, program itu akan lebih sesuai dengan kebutuhan masyarakat dan tingkat kepedulian masyarakat dalam menjalankan program/kebijkan akan lebih tinggi. Pengabdian masyarakat ini membantu masyarakat untuk memahami pengampunan pajak, penghitungan dan pelaporan pajak sehingga membantu Dirjen Pajak dalam mensosialisasikan pajak pelaku UMKM.

\section{HASIL DAN PEMBAHASAN}

Dari hasil identifikasi permasalahan pada hasil penelitian yang sudah dilakukan tentang pada pelaku UMKM di kampung batik Kota Semarang, dimana masih rendahnya kesadaran pelaku UMKM tentang pelaporan pajak sebagai pelaku usaha UMKM dan ketidaktahuan tentang tarif pajak UMKM yang sudah diringankan oleh pemerintah.

Berdasarkan kondisi rendahnya pengetahuan tentang pajak oleh pelaku UMKM maka salah satu program pengabdian yang menjadi prioritas untuk dilaksanakan adalah: (1) Sosialisasi perhitungan wajib pajak usaha mikro, kecil dan menengah (UMKM) di kelurahan Tambakharjo, kecamatan semarang barat kota semarang; (2) Pelatihan pelaporan wajib pajak usaha mikro, kecil dan menengah (umkm) di kelurahan tambakharjo, kecamatan semarang barat kota semarang

Pelaksanaan pengabdian dengan tajuk

"Pengabdian Sosialisasi Perhitungan Dan Pelaporan Wajib Pajak Usaha Mikro, Kecil dan Menengah (UMKM) di Kelurahan Tambakharjo, Kecamatan Semarang Barat Kota Semarang" ini di kemas dalam 3 sesi:

Sesi I, merupakan pengarahan Pentingnya berpartisipasi dalam membayar pajak sebagai pelaku UMKM oleh Drs. Saryadi,M.Si dari Departemen Administrasi Bisnis Fakultas Ilmu Sosial dan Ilmu Politik UNDIP.

Sesi II, merupakan materi Perhitungan Dan Pelaporan Wajib Pajak Usaha Mikro, Kecil dan Menengah (UMKM) oleh M.Abdul Sjuchur mantan Pejabat Direktorat Jenderal Pajak Republik Indonesia yang terus aktif 
mensosialisasikan dan sebagai tempat konsultan bagi wajib pajak di Kota Semarang.

Sesi III, merupakan penutupan dan komitmen bersama untuk membayar pajak sebagai pelaku UMKM di Kota Seamrang sekaligus photo bersama dengan penyerahan brosur sosialisasi pajak dan penawaran untuk jasa bantuan konsultasi pajak bagi pelaku UMKM Kota Semarang

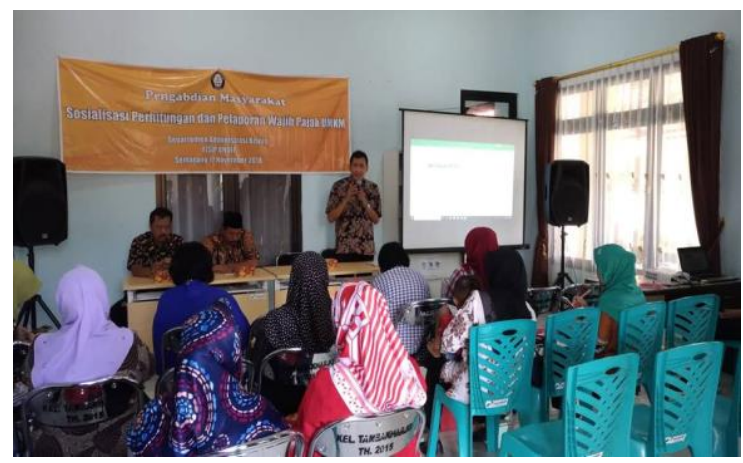

Gambar 1.Pengarahan Pentingnya Berpartisipasi Dalam Membayar Pajak Sebagai Pelaku UMKM

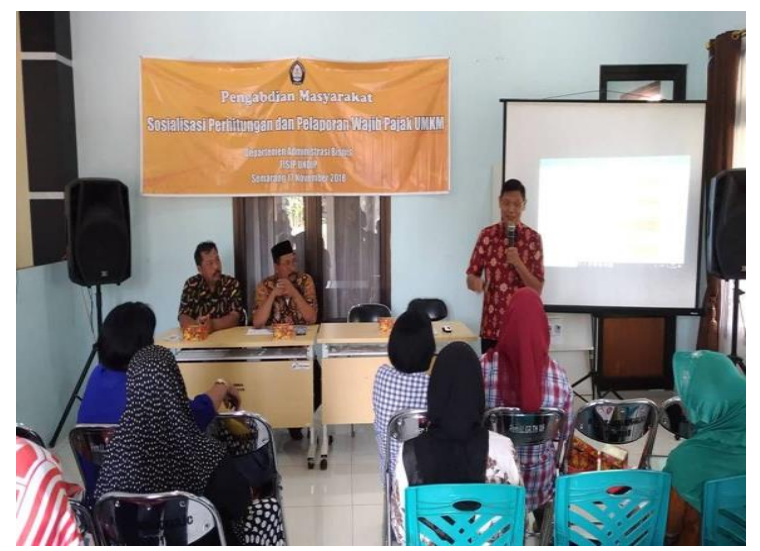

Gambar 2. Sosialisasi Perhitungan Dan Pelaporan Wajib Pajak Usaha Mikro, Kecil dan Menengah (UMKM)

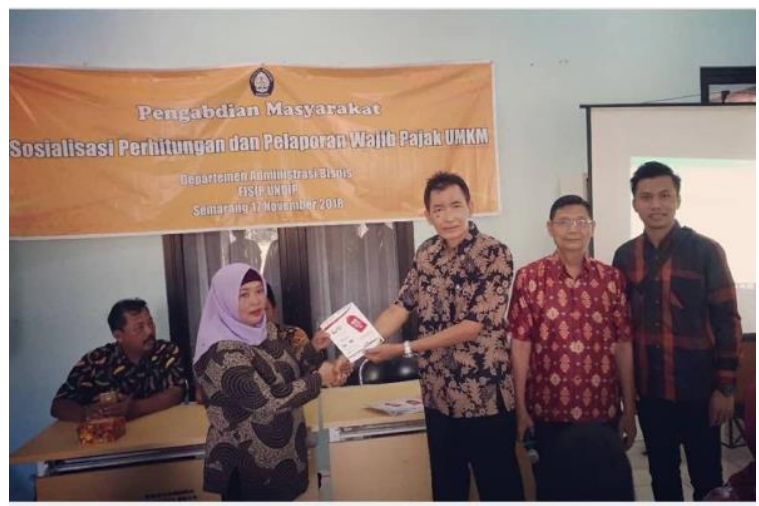

Gambar 3. Penutupan Dan Komitmen Bersama Untuk Membayar Pajak

Gunadi. (2005). "Fungsi Pemeriksaan terhadap Peningkatan Kepatuhan Pajak (Tax Compliance)". Kepada pelaku UMKM Kota Semarang sampai paham akan alur pelaporan pajak sehingga tidak ragu atau enggan melaporkan pajak mereka sebagai pelaku wajib pajak UMKM. Pendampingan yang dilakukan tidak hanya memberikan pengetahuan tapi juga mereka bisa mengontak kapan saja jika membutuhkan bantuan untuk pengisian atau pelaporan pajak UMKM yang mereka kelola.

\section{DAFTAR RUJUKAN}

Adimihardja, K. \&. H. H., 2003. Participatory Research Appraisal: Pengabdian dan Pemberdayaan Masyarakat. Bandung: Penerbit Humaniora.

Agung, Mulyo. (2007). Teori dan Aplikasi Perpajakan Indonesia. Jakarta: Penerbit Dinamika Ilmu.

Ayu, Claressa. 2017. Pengaruh Perubahan Tarif, Kemudahan Membayar Pajak, Sanksi Pajak, dan Sosialisasi PP. Nomor 46 Tahun 2013 Terhadap Tingkat Kepatuhan Wajib Pajak Pelaku UMKM. Journal Retreived. Vol 4. No.5

Bhandari, B. B., 2003. Participatory Rural Appraisal. In: Kanagawa, Japan: Institute for Global Environmental Strategies (IGES), p. Module 4.

Endrianto, Wendy. 2015. Prinsip Keadilan dalam Pajak UMKM. Jurnal: Binus Business Review Vol. 6 No. 2

Indrawan, Rizki, dkk. 2018. Pemahaman Pajak dan Pengetahuan Pajak 
Saryadi, Pinem. Sosialisasi perhitungan dan pelaporan

Terhadap Kepatuhan Wajib Pajak UKM Understanding of Taxes and Knowledge of Taxes on Compliance with SME Taxpayers. Jurnal Riset Akuntansi dan Keuangan Vol.6, No.3

Kariyoto, dkk. 2012. Pengaruh Kesadaran dan Kepatuhan Wajib Pajak Terhadap Kinerja Perpajaka. Jurnal Akuntansi dan Multiparadigma. Volume 3. No.1

Mukhlis, Imam \& Simanjuntak, Timbul Hamonangan, (2016). "Tax Compliance for Bussinessmen of Micro, Small and Medium

Enterprises Sector In The Regional Economy". International Journal of Economics, Commerce and Management. Vol. 4, Issue 9.

Munari. 2005. Pengaruh Faktor Tax Payer terhadap Keberhasilan Penerimaan Penghasilan. Jurnal Eksekutif, Vol. 2, No. 2.
Primandani, Inka.dkk. 2017. Analisis Perilaku

Kepatuhan, Pemahaman, dan Kemudahan Wajib Pajak UMKM Terhadap Peraturan Pemerintah No.46 Tahun 2013 Pada KPP Pratama Mulyorejo. Jurnal Ekonomi Akuntansi, Vol.3 Issue.3

Supadmi, N.L. 2010. Meningkatkan Kepatuhan Wajib Pajak Melalui Kualitas Pelayanan. Jurnal FE Unud. Volume 4.

Winerungan, Lidya Oktaviane.2013. Sosialisasi Perpajakan, Pelayanan Fiskus, dan Sanksi Perpajakan Terhadap Kepatuhan WPOP di KPP Manado dan KPP Blitung. Jurnal EMBA Vol.1 No.3

Yusro, Wachidatul Heny dan Kiswanto.2014. Pengaruh Tarif Pajak, Mekanisme Pembayaran Pajak, dan Kesadaran Membayar Pajak Terhadap Kepatuuhan Wajib Pajak UMKM di Kabupaten Jepara. Accounting Analysis Journal Vol.3 No.4.

Undang-Undang, Nomor 11 Tahun 2016, tentang "Pengampunan Pajak", Jakarta, 2016 